\title{
STUDY OF GEOGRAPHY COURSEBOOKS IN INDIA. AN EXAMPLE SET BY MAHARASHATRA STATE
}

\author{
MARI ANA-DOINA CÎINEANU \\ "Nicolae Bălcescu" National College, Brăila, Brăila County, e-mail: officeroseromania@gmail.com
}

(Received: July 2016; in revised form: August 2016)

\begin{abstract}
The introduction conveys some data on the system of education in India, about the place Geography occupies within the curriculum, and on geography teachers' training. In the first section of the paper, several features of the coursebooks in India are underlined: authors, editing, prices, and designing. Furthermore, an array of coursebooks for $4^{\text {th }}, 5^{\text {th }}, 6^{\text {th }}, 7^{\text {th }}$, and $8^{\text {th }}$ grades is presented. As regards each coursebook, there are scrutinized: the table of contents (topics), the texts, illustrative/iconic materials (maps, photographs, and schematic charts), exercises, the amount of geography terms and denominations, and the glossary.
\end{abstract}

Keywords: curriculum, exercises, secondary education, education system, geography learning, geography rationale

\section{INTRODUCTION}

The system of education in India is divided into several stages: the preschool cycle, primary education $-1^{\text {st }}-4^{\text {th }}$ grades, first secondary education $5^{\text {th }}-7^{\text {th }}$ grades, higher secondary education (high school) $-8^{\text {th }}-10^{\text {th }}$ grades, as well as "Junior College" cycle $-11^{\text {th }}-12^{\text {th }}$ forms (high school). At the end of the $10^{\text {th }}$ grade, students sit a National Assessment exam, without any other previous assessments.

The school year makes its debut on the $21^{\text {st }}$ of June and ends on the $15^{\text {th }}$ of April. The holiday in-between the school years lasts from the $16^{\text {th }}$ of 
April until the $20^{\text {th }}$ of June. There are as well two more brief holidays: a two-week one in October and a one-week vacation in December. The school year comprises 40 course weeks, whereas in Romania it consists of 36 weeks, which means that the students in India spend at school one more month unlike the students in our country.

Geography is studied starting with the $3^{\text {rd }}$ grade. In first and higher secondary education, there are allotted minimum 2 hours per week (sometimes 3 hours). During the secondary-education stage, besides Geography, students also study Math, Sciences (Biology, Chemistry, Physics), Social sciences (Geography-History-Constitution), PE, and Art and Handicrafts. These subjects are compulsory until the $10^{\text {th }}$ grade. Until the $5^{\text {th }}$ grade, they also learn: Music, Dance, and Arts. The Indians learn at least three languages: English - official language, Standard Hindi - compulsory national language and the third is at choice from either the language of the said state (e.g. Marathi for Maharashtra) or Sanskrit. Students do not attend optional courses in school in order to elude a too busy schedule; still there is the option of extra-curricular courses, which are available as private lessons.

Teachers who have majored in Geography teach geography in secondary schools. They have attended for three years the Arts Faculty which comprises the specialties of literature, history, geography; then they do an MA programme which lasts approximately two years, of geographypedagogic (for the first secondary education: Bachelor of Education, for High School the Bachelor of Education is unnecessary). Another sort of MA is dedicated to History, Geography and Literature. Geography teachers feature a single major. They can teach Geography starting with the $3^{\text {rd }}$ grade up to $12^{\text {th }}$ grade. The didactic teaching norm for secondary education is of aproximately 25 conventional hours per week. Classes start at 09:30 and finish at 15:30, including a lunch break.

The Curriculum for the $4^{\text {th }}-8^{\text {th }}$ grades, in accordance with which have been designed the coursebooks I analysed, has been established by the National Curricular Framework 2000, the Primary Education Curriculum 2004 and the 2006-2007 Programme. India has a two-fold Domestic Education Programe - ICSE (Indian Certificate of Secondary Education), displaying a strong practical feature, used mainly for the first and higher secondary education, and CBSC (Central Board of Secondary Education) broadly theoretical, more difficult, which is not approved by all states of India. Apart from these programmes established at central level, there are syllabusi provided at the level of each state. The coursebooks we analyse are compliant with the education syllabus for the State of Maharashtra.

\section{THEORETICAL BASIS. THE FEATURES OF INDIAN COURSEBOOKS}

The coursebooks we scrutinize have been designed under the aegis of the Council for Maharashtra State Board of Secondary and Higher Secondary Education, by a Board of Editors for Geography under the guidance of a 


\section{STUDY OF GEOGRAPHY COURSEBOOKS IN INDIA. AN EXAMPLE SET BY MAHARASHATRA STATE}

Board of Studies, and have been edited by Maharashtra State Bureau of Textbook Production and Curriculum Research (Pune 411004).

The coursebooks are designed and edited at the level of each state. For the Maharashtra State, one of the best school publishers is Balbharati. For a school subject/school year, there are available one or two coursebooks. The coursebooks are not free, but still at an affordable price. According to the publisher and price, the school decides what coursebooks to use in class.

In this paper, we shall present the geography coursebooks for first secondary education and the one for the $8^{\text {th }}$ grade. The coursebooks have been structured according to an analytical programme which, starting with the $3^{\text {rd }}$ grade, implements sequentially aspects of geography characteristic of each school year. On the cover of every coursebook, it is written Geography and the study year to which it is assigned (that is, Geography Standard Five).

The authors are a panel of learned persons ranging from geographers, cartographers, photographers, pedagogues, revisers, tenured teachers with experience in the field, economists, experts, and professors. For instance, the $5^{\text {th }}$ grade coursebook was frist printed in 2006 and its second impression was in 2013. It was elaborated with the aid of the following personnel: 8 members of the Board of Editors for Geography, 2 responsible with the illustrations, 1 in charge of the maps, 4 coordinators, 5 translators, 1 reviser, 6 responsible persons with the production. This example highlights that, in the process of designing a coursebook, there is involved a considerable array of specialists from more domains, who are coordinated by the Board of Editors for Geography. This Board is the broadest for the $5^{\text {th }}$ grade comprising 8 members, out of which 2 are PhD teachers; for the $6^{\text {th }}$ grade, there are 6 members, out of which 3 are PhD teachers; for the $7^{\text {th }}$ grade, there are 7 members, out of which 2 are PhD teachers; for the $8^{\text {th }}$ grade, there are 6 members, out of which 1 is a PhD teacher. Besides this aspect, the component of the panel of editors is similar.

The coursebooks run the whole gamut of components: the ten life standard practices and skills, Foreword, excerpt from the Indian Constitution, Pledge, Word to the teachers and parents, objectives, lessons, and glossary. The coursebooks' dimensions are the following: length $28 \mathrm{~cm}$, width $21 \mathrm{~cm}$ (approximately as an A4 page).

\section{RESULTS}

THE $4^{\text {TH }}$ GRADE COURSEBOOK (Board of Editors for Geography, 2013)

The Geography Standard Four coursebook has 60 pages. It opens with the ennumeration of the ten life skills education for teens and continues with the Foreword, Pledge, Contents, lessons, maps, and Glossary. 
(1) Life skills education. The Board of Indian teachers and experts have inserted in the basis of recommendations from the World Heath Organisation (WHO) a set of ten life skills that students should acquire. These skills aimed at enhancing students' innate abilities to be capable of leading their life in a beautiful and auspicious mode. So that these skills are acquired, it is significant that children be provided with all opportunities necessary in the very first segment of their life.

An important objective for the Indian teachers is that of enabling the development of students' personality by making them use their own physical and intellectual qualities. These skills are practised and the students comprehend them properly if these are related to the didactic objectives. The 10 life skills presented in Geography Standard Four (on the inside of the front cover) are the following:

- self-awareness: the ability to be aware of one's own abilities, limits, preferences and aims;

- empathy: the ability to sympathise with others' feelings or experiences by placing oneself in the others' place;

- problem solving: the ability to opt from a range of more valid choices, the one which is beneficial and which stands the highest chance of achievement and to act accordingly;

- decision taking: the ability, in the process of problem solving, to discover some possible solutions and to agree on the proper ones;

- efficient communication: the ability to express one's thoughts verbally or non-verbally and to reach the target;

- critical thinking: the ability to objectively analyse and examine the received information;

- creative thinking: the ability to consider an issue or a situation in a non-conventional innovative mode, other than in a manner imposed by customs or traditions;

- interpersonal relationships: the ability to relate to the people they meet day by day and to develop honest and cordial relationships with these ones;

- coping with emotions: the ability to identify both one's own and others' emotions, anticipating consequences, and the capacity of handling them properly;

- coping with stress: the ability to identify the causes of the stress, to be aware of the physical and psychical effects it instills and to handle these efficiently.

(2) Foreword (the very first page of the coursebook, but which is not numbered). Here it is stated the objective so that students acquire the ten life skills, and teachers are invited to adopt this standpoint regarding teaching Geography in class. It is mentioned the fact that the coursebook text was devised as reliant on a certain vision, stressing that the teachinglearning process is to be centred on students, which means that the method 


\section{STUDY OF GEOGRAPHY COURSEBOOKS IN INDIA. AN EXAMPLE SET BY MAHARASHATRA STATE}

of individual study ought to enjoy greater importance so that the learner be able to form the desired skills, and, on this account, the education process should become pleasant and interesting.

(3) Pledge: Here there are displayed the feelings and convictions which each Indian teeanager should be endowed with towards their country, people, parents, teachers, and all those older than themselves.

"India is my country. All Indians are my brothers and sisters. I love my country and I am proud of its rich and varied heritage. I shall always strive to be worthy of it. I shall give my parents, teachers and all elders respect and treat everyone with courtesy. To my country and my people, I pledge my devotion. In their well-being and prosperity alone lies my happiness." (the second page of the coursebook, again not numbered).

(4) Contents. In the $4^{\text {th }}$ grade, they study the Geography of the state which the student is a citizen of. Within this section, there are presented the topics, pages and the skills intended to be enhanced. The themes to be studied in the $4^{\text {th }}$ grade and the consequent skills to be developed range as follows:

1. Measurement of Time - skill $3-p p \cdot 1-3$

2. Earth's Spheres - skills 6, 10 - pp. 4-6

3. Natural Environment - skills 1, 2, 3, 6, 10 - pp. 7-8

4. Our Maharashtra State - skills 1, 6 - pp. 9-11

5. Maharashtra - Physical - skills 3, 6 - pp. 12-16

6. Maharashtra - Climate - skills 3, 6 - pp. 17-19

7. Maharashtra - Population and Human Life - skills 2, 3, 7, 8, 9 - pp. 2023

8. Maharashtra - Water and Marine Resources - skills 2, 9 - pp. 24-27

9. Maharashtra - Forests and Wild Life - skills 1, 2 - pp. 28-32

10. Maharashtra - Minerals and Energy Resources - skill 7 - pp. 33-36

11. Maharashtra - Agriculture - skills 2, 7 - pp. 37-43

12. Maharashtra - Industries - skill 7 - pp. 44-46

13. Maharashtra - Transport, Communnication, and Trade - skill 4 - pp. 47-49

14. Maharashtra: Major Cities and Tourist Places - skill 10 - pp. 50-54

15. Map Reading and Field Visit - 1, 4, 5, 6 - pp. 55-56

At the end of each topic, there are provided three drills with distinct items and an activity or a project adapted to students' age. 
(5) The Glossary comprises an array of Geography terms that are employed in the coursebook lessons. Their meaning should be understood by the students so as they may use them in conversation.

(6) Mute maps. At the beginning and at the end of the coursebook, there are added mute maps to be used as photocopiable materials (for instance, in this coursebook there are the Mute Map of Maharashtra state divisions and the Map of Rivers)

THE $5^{\text {TH }}$ GRADE COURSEBOOK (Board of Editors for Geography, 2013)

The Geography Standard Five coursebook encompasses 76 pages. The coursebook comprises the Foreword, an excerpt from the Indian Constitution, Pledge, Contents, lessons, Glossary, and maps. The data, which I have presented for the Foreword and Pledge, bear the same content for all first and higher secondary-school coursebooks, being the ones stated in the $4^{\text {th }}$ grade coursebook. It is mentioned, in the word for teachers and parents (p. 4, not numbered) the fact that the coursebook includes charts and maps enabling the teaching-learning of Geography. It is stated that the activities are adequate for the $5^{\text {th }}$ grade students, although some feature a higher difficulty degree, requiring help and guidance on belhalf of the teacher. It is appropriate the introduction of certain new words in the Glossary, explaining their need. The novelty consists of the insertion of a brief 5-6-line summary at the beginning of each topic, which reveals its key elements. At the closing of each topic, there are three drills and, sometimes, a project-like activity.

(1) Contents. Geography Standard Five focuses on the study of India. The coursebook includes the following themes:

1. Shape of the Earth - pp. 1-2

2. Locating a Place on the Earth - pp. 3-5

3. Local Time and Standard Time - pp. 6-7

4. Map Reading and Field Visits - pp. 8-10

5. Atmosphere - pp. 11-12

6. Climate - pp. 13-14

7. Biosphere - pp. 15-16

8. India - Location and Extent - pp. 17-18

9. India - Physical Divisions - pp. 19-22

10. India - Rivers - pp. 23-25

11. India - Climate - pp. 26-27

12. India - Water Resouces and Marine Wealth - pp. 28-29 
13. India - Forest Wealth and Wildlife - pp. 30-31

14. India - Mineral Wealth and Energy Resources - pp. 32-36

15. India - Population and Life of the People - pp. 37-40

16. India - Occupations of the People - pp. 41-44

17. India - Industries - pp. 45-47

18. India - Transports, Communication and Trade - pp. 48-51

19. India - Cities and their Development - pp. 52-54

20. India - Tourism - pp. 55-56

21. India - The Problem of Pollution - pp. 57-59

(2) Topic presentation. I have scrutinized the following aspects: text length for each topic, lesson structure, the type of documents included in the presentation of topics, the amount of Geography terms and words explained in the Glossary.

Table 1a. Text length of the topics in Geography Standard Five coursebook

\begin{tabular}{|l|l|l|l|l|l|l|l|l|l|l|l|}
\hline Topic & $\mathbf{1}$ & $\mathbf{2}$ & $\mathbf{3}$ & $\mathbf{4}$ & $\mathbf{5}$ & $\mathbf{6}$ & $\mathbf{7}$ & $\mathbf{8}$ & $\mathbf{9}$ & $\mathbf{1 0}$ & $\mathbf{1 1}$ \\
\hline No. of text lines & 40 & 62 & 51 & 86 & 49 & 61 & 32 & 25 & 84 & 64 & 53 \\
\hline
\end{tabular}

Table 1b. Text length of the topics in Geography Standard Five coursebook

\begin{tabular}{|l|l|l|l|l|l|l|l|l|l|l|}
\hline Topic & $\mathbf{1 2}$ & $\mathbf{1 3}$ & $\mathbf{1 4}$ & $\mathbf{1 5}$ & $\mathbf{1 6}$ & $\mathbf{1 7}$ & $\mathbf{1 8}$ & $\mathbf{1 9}$ & $\mathbf{2 0}$ & $\mathbf{2 1}$ \\
\hline No. of text lines & 48 & 66 & 74 & 102 & 82 & 68 & 79 & 90 & 28 & 54 \\
\hline
\end{tabular}

Lesson structure. Some lessons are scaffolded according to numbered themes $(2,4,6,7,8,11,13,15,16,17,18,19$, and 21); others appear arranged in bulletted items and sub-theme (5, 9, 10, and 14). There are lessons that do not appear as structured (1,3, 12, and 20).

The Illustrative/Iconic material included per lesson in the coursebook is varied, rich, accurate, and adequately connected to the text. Topic 9 Physiographic Divisions of India unfolds six maps: India's Map Physiographic Divisions; the Map of the North mountainous regions and North-Indian plains; the Map of the Indian Plateau and of the low seaside coasts; Nicobar and Andaman islands; Lakshasweep Island; the Physical Map of India. Within this section, there are two relief profiles from the $\mathrm{W}$-E and N-S directions, too.

The amount of geographical terms. Concerning Topic 5 Atmosphere, there are 41 geography terms: drought, flood, climatic, meteorological, atmosphere, environment, vegetation, land, biosphere, air, lithosphere, hydrosphere, movements, gases, dust, sun, storms, volcanoes, 
mining, temperature, troposphere, clouds, rainfall, stratosphere, motions, ozone, ultraviolets, life/livelihood, mesosphere, ionosphere, radio waves, telecommunications, thermosphere, lifting gases, hydrogen, carbon dyoxide, protecting shield, fuel, global warming, mankind, pollution (pp. 1112). We notice that these notions are related not only to the atmosphere, but also to other topics, which indicate a cross-disciplinary and transdisciplinary approach and the compliance with the principle of intergrating the geographical elements in the study of the processes and phenomena that are caused within the geographic layers. The Glossary defines 10 terms from the ones listed previously: atmosphere, biosphere, hydrosphere, lithosphere, temperature, troposphere, stratosphere, mesosphere, thermosphere, and ionosphere.

Map-related drills. For each topic in the coursebook, there are exercises by means of which students learn how to analyse and interpret the content of maps, how to position oneself with the aid of maps and how to be aware of the geographical space. In this coursebook, there are also tasks based on various experiments. We hereby present two learning activities from Topic 2 - Localising a point on the globe.

Activity 1: Localise Itanagar and Gandhinagar using the Political Map of India. Ask the teacher to help you in order to find the longitudinal distance between the two places. (p. 5)

Activity 2: Highlighting the light circles.

Objective: to grasp what the circle of light is.

Props: a rubber ball with a diametre of $7.7 \mathrm{~cm}$, a candle, a box.

Unfolding of the experiment: 1) place the candle on the desk; 2) put the ball at a certain distance from the candle.

Results:

- notice the ball from distinct angles;

- if viewed from the side of the candle, you will see the entire lit part of the ball;

- if viewed from the opposite side of the candle, one will observe its whole dark part;

- holding both the ball and the candle in front of you, you will be able to see the vertical line which divides the lighted side form the darkened one.

- observe this line from all angles.

Conclusion: the line that divides the lit side from the darkened one is known as the Light Circle (p. 5).

(3) The Glossary encompasses 73 terms connected with the content of the subject, providing simple explanations. With regard to Topic 13 Wood and fauna resources, the following notions are explained in the Glossary: habitat, biodiversity, deciduous forest, salinity, mangrove ( $p$ p. 30-31). The Glossary is displayed alphabetically. 


\section{STUDY OF GEOGRAPHY COURSEBOOKS IN INDIA. AN EXAMPLE SET BY MAHARASHATRA STATE}

(4) Maps, figures, drawings and images are clear, representative, complex, and accurate. They are not laden with insignificant data and are an accurate representation of the region. The coursebook encompsses six important maps, out of which two are at the beginning of the coursebook (Maps 1 - India's Map revealing the component states, without their denominations, and the Complex Map of India/the Political Map; Map 2 the World Map comprising the continents, the outlines of the states, the official hour on the globe and the local hour of India, the main parallels and meridians, two in the middle (Map 5 - the Physical Map of India, profiles WE, N-S; Map 6 - the Traffic Map) and two at the end (Map 3 - Map of Woods and Natural Reserves of India; Maps 4 - the Map supplying conventional signs and the Map providing useful elements for hiking). Apart from these six main maps, in the coursebook, there are other 21 thematic maps.

THE 6 $^{\text {TH }}$ GRADE COURSEBOOK (Board of Editors for Geography, 2012)

The Geography Standard Six coursebook contains 72 pages. It encompasses the Foreword, an excerpt from the Indian Constitution, Pledge, Contents, lessons, Glossary, and maps. The data which I have presented for the Foreword and the Pledge bear the same content for all secondary-school coursebooks, being the ones stated in the $4^{\text {th }}$ grade coursebook. The word for teachers and parents ( $p .4$, not numbered) announces again the fact that the coursebook encloses charts and maps so as to enable the teachinglearning of Geography, moreover that the experiments presented in the coursebook are meant to grant the insight of some technical notions derived from each chapter. Teachers are recommended to rely on these (figures, maps, experiments) and to employ these on a regular basis. It is stated that the activities are adjusted to the particularities of age, but that there is a permanent need to receive the teachers' help so as to properly complete the projects and activities.

The beginning of each topic in the coursebook harbours an ample 1011-line summary, whilst the closing of every topic includes 3-4 drills. The schematic drawings are very useful to understand the phenomena and processes and they are represented in a simple manner, intuitively. The content of the tables and the examples are relevant for each topic.

(1) Contents. Geography Standard Six encompasses themes of Physical Geography (ranging from 1 to 11 ) and some themes of Regional Geography (arraying from 12 to 19):

1. The Solar System - pp. 1-3

2. Motions of the Earth and their Effects - pp. 4-5

3. Seasons - pp. 6-8

4. Local Time and International Date Line - pp. 9-11 
5. Scale of a Map and Field Visit - pp. 12-14

6. Air Temperature - pp. 15-17

7. Air Pressure - pp. $18-20$

8. Winds - pp. 21-23

9. Rain - pp. 24-26

10. Biosphere - pp. 27-29

11. Natural Regions - pp. 30-31

12. The World - An Introduction - pp. 32-33

13. Asia - Physical - pp. 34-35

14. Asia - Resources - pp. 36-39

15. Israel - pp. 40-42

16. Saudi Arabia - pp. 43-45

17. Malaysia - pp. 46-48

18. Japan - pp. 49-51

19. Sri Lanka - pp. 52-54

(2) Analisys of the lesons in the coursebook. In Table 2, we put forward the length of the texts from this coursebook. The text of a lesson ranges from 38 to 99 lines. This text span lays an emphasis in accordance with the students' time resources available for reading, as well as with their age.

In lessons, there are charts revealing figures for topic 1 (12 rows) and tables of verbal data for topic 8 ( 12 rows); experiments for topics 2 ( 15 lines), 7 (18 lines), 9 ( 6 rows), and 10 ( 6 lines); explanations within topics 11 (4 lines), 13 (10 lines), 17 (3 rows); activites (games) found in topics 10 and 11 (5 lines).

Table 2a. Text span of the topics in Geography Standard Six coursebook

\begin{tabular}{|l|l|l|l|l|l|l|l|l|l|l|}
\hline Topic & $\mathbf{1}$ & $\mathbf{2}$ & $\mathbf{3}$ & $\mathbf{4}$ & $\mathbf{5}$ & $\mathbf{6}$ & $\mathbf{7}$ & $\mathbf{8}$ & $\mathbf{9}$ & $\mathbf{1 0}$ \\
\hline No. of text lines & 76 & 38 & 67 & 71 & 75 & 90 & 58 & 83 & 62 & 97 \\
\hline
\end{tabular}

Table 2b. Text span of the topics in Geography Standard Six coursebook

\begin{tabular}{|l|l|l|l|l|l|l|l|l|l|}
\hline Topic & $\mathbf{1 1}$ & $\mathbf{1 2}$ & $\mathbf{1 3}$ & $\mathbf{1 4}$ & $\mathbf{1 5}$ & $\mathbf{1 6}$ & $\mathbf{1 7}$ & $\mathbf{1 8}$ & $\mathbf{1 9}$ \\
\hline No. of text lines & 67 & 62 & 63 & 115 & 94 & 75 & 87 & 99 & 78 \\
\hline
\end{tabular}

Lesson structure. The lessons are divided into numbered themes $(1,2,3$, $11,12,13,14,15,16,17,18$, and 19), as bulletted items and sub-themes $(6,7,8,9$, and 10). Some lessons are devoid of sub-themes (topic 4).

Illustrative/Iconic material included per lesson. With Topic 7 Atmospheric Pressure - there are 7 figures: Figure 1, showing an experiment demonstrating that the air indeed features its own weight; Figure 2 - The Map of the Atmospheric Pressure Distribution (in milibars); 


\section{STUDY OF GEOGRAPHY COURSEBOOKS IN INDIA. AN EXAMPLE SET BY MAHARASHATRA STATE}

Figure 3 - Areas of Pressure of the Earth and permanent Winds; Figure 4 Aneroid Barometres - pressure measuring instrument (pp. 18-20).

The quantity of geographical terms. With Topic 8 - Wind (pp. 21-23), there are 56 specific geographical terms: wind, Earth surface, pressure, speed, direction, weathervane, rotation, hemispheres, the Northern Hemisphere, the Southern Hemisphere, parallel $45^{\circ}$, the Ecuator, region, warm, South-East, North-East, planetary, local, seasonal, polar, West, East, subpolar, climates, mountainous, valley, days, peak, cold, ridge, breeze, night, temperature, coasts, sea water, dry, soil, temperature, shores, foëhn, monsoon, summer, winter, plain, season, cyclone, region, anticyclone, rainfall, cold, warm, sea waves, oceanic currents, energy, power, and eolian windmills.

Amount of geographical denominations. Concerning Topic 8 - Wind ( pp. 21-23), there are 26 geographical denominations: Argenine, Chinook, Bora, Loo, India, Sri Lanka, Myanmar, Japan, West Indies, Australia, Africa, France, The Alps, The Rocky Mountains, Saudi Arabia, Iran, Maharashtra, Santa Ana, Khamsin, Samun, Zonda, Harmattan, Strol, Pampero, Southerly, Buster, and Greece. This range of denominations indicates quite broad an array, especially considering that students ought to be able to pinpoint on the map so as to deeply understand how the winds are formed on the globe and which their significance is in relation to other components of the environment.

Drills related to the maps/drawings. For Topic 11 - Natural Regions, the following activities are mentioned.

Activity 1: Let's play! The images besides show along one row various types of vegetation, and along the other row, distinct animals; trace arrows between the vegetation and animals (pastures, spiny shrubs, taiga, Equatorial forests / gorilla, polar bear, hare, camel (page 1, not numbered at mid-coursebook).

Activity 2: Let's play! Below, the outlines of several countries are provided; identify what countries, out of the studied ones, these drawings represent; colour the maps and write their name (page 1, not numbered at mid-coursebook).

(3) The Glossary includes 73 terms linked to the contents. For every notion, a simple definition is offered, to enable students' understanding. I took as example Topic 8 - Wind. In this respect, the Glossary discloses the following terms: wind, weathervane, permanent winds, seasonal winds, local winds, Eastern Winds, Western Winds, Polar Winds, cyclone, and anticyclone.

(4) Illustrative/iconic material. The coursebook consists of eleven figures, out of which three are at its beginning (i.e. Figure 1 - Planiglobe with the hours per day, the hours of the clock, Meridians, sunrise in New Orleans, lunch in Accra, sunset at Patna, midnight in Tokyo; Figure 2 - the World's Natural Regions; Figure 3 - the 4 hemispheres of the Earth) (p. 1, not numbered, at the beginning of the coursebook), five at mid-coursebook (Figure 4 - the Map of Asia: mountains, hills, plains, rivers, and the 
surrounding seas; Figure 5 - the Map of Asia: the important countries; Figure 6 - the Map of Asia: flora and fauna; Figure 7 - the Physical Map of Israel; Figure 11 - the Physical Map of Sri Lanka) (p. 2, not numbered, at the middle of the coursebook); and three at the end of the coursebook (Figure 8 - the Physical Map of the Saudi Arabia; Figure 9 - the Physical Map of Malaysia; Figure 10 - the Physical Map of Japan). Apart from these 11 main figures, inside this material there are other 17 thematic maps (pp. $6,7,11,15,16,17,18,19,21,25,33,38,41,44,47,50,53)$.

THE $7^{\text {TH }}$ GRADE COURSEBOOK (Board of Editors for Geography, 2012)

The Geography Standard Seven coursebook contains 72 pages. It opens with an excerpt from the Indian Constitution, Pledge, Contents, lessons, Glossary and maps, and the 10 life skills. The data which I have presented for the life skills, Foreword and Pledge bear the same content as the one displayed in the $4^{\text {th }}$ grade coursebook. The word for teachers and parents (p. 4, at the beginning of the coursebook, not numbered) reminds that the activities are adjusted to the particularities of age, it is acknowledged the importance of the explanations at the right moment in the form of game and based on dialogue, placing students at the centre of the lesson, benefitting from teachers' help for the most difficult tasks.

The 10 skills appear at the beginning of the coursebook. It is therefore emphasized their being taken into consideration a priori the process of teaching-learning, and that lesson planning be in accordance with these.

(1) Contents. Geography Standard Seven displays themes of Physical Geography (ranging from 1 to 8), of Human Geography (themes 9-10) and the themes of Regional Geography (arraying from 11 to 18):

1. The Universe - skills 1, 4, 5, 6- pp. 1-3

2. The Sun, the Earth and the Moon - skills 1, 4, 5, 6, 7-pp. 4-7

3. The Map - skills 1, 4, 5, 6-pp. 8-11

4. Field Visit - skills 1, 3, 4, 5, 6, 9, 10 - pp. 12-13

5. Hydrosphere - skills 4, 5, 6-pp. 14-16

6. Ocean Floor Relief and Oceanic Oozes - skills 5, 6 - pp. 17-18

7. Temperature and Salinity of Ocean Waters - skills 5, 6 - pp. 19-21

8. Movements of Ocean Water - skills 5, 6-pp. 22-25

9. Human Occupations - skills 3, 6, 8, 9 - pp. 26-27

10. Population - skills 4, 6, $10-p p .28-30$

11. The Continent of Africa - skills 5, 6, 7, 8, 9 - pp. 31-34 
12. The Continent of North America - skills 5, 6, 7, 8, 9 - pp. 35-37

13. The Continent of South America - skills 5, 6, 7, 8, 9 (lesson for selfstudy) - pp. 38-40

14. The United States of America - skills 2, 3, 5, 6, 7, 8, 9 - pp. 41-45

15. Brazil - skills 2, 3, 5, 6, 7, 8, 9 - pp. 46-49

16. Egypt - skills 2, 3, 5, 6, 7, 8, 9 - pp. 50-53

17. Tanzania - skills 2, 3, 5, 6, 7, 8, 9 - pp. 54-57

18. South Africa - skills 2, 3, 5, 6, 7, 8, 9 (lesson for self-study) - pp. 58-62.

(2) Analysis of the lessons. Each lesson opens with a five-line summary. The images, maps, drawings and scientific data are very well chosen. The content of the text of a theme does not surpass more than one page. At the end of the lessons, there are three drills and the students are recommended a more complex activity by realising a project.

In Table 3, I have shown the length of the texts for each theme. It is conspicuous that the span of a theme text ranges from 31 to 119 lines. In the coursebook, there are tables for themes 1 (5 lines), 3 (18 lines), 7 (10 lines), and 11 (23 lines). There are provided explanations for themes 5 ( 5 lines) and 15 ( 8 lines).

Table 3a. Text span of the topics in Geography Standard Seven coursebook

\begin{tabular}{|l|l|l|l|l|l|l|l|l|l|l|}
\hline Topic & $\mathbf{1}$ & $\mathbf{2}$ & $\mathbf{3}$ & $\mathbf{4}$ & $\mathbf{5}$ & $\mathbf{6}$ & $\mathbf{7}$ & $\mathbf{8}$ & $\mathbf{9}$ & $\mathbf{1 0}$ \\
\hline No. of text lines & 49 & 79 & 65 & 31 & 76 & 50 & 36 & 97 & 64 & 81 \\
\hline
\end{tabular}

Table 3b. Text span of the topics in Geography Standard Seven coursebook

\begin{tabular}{|l|l|l|l|l|l|l|l|l|}
\hline Topic & $\mathbf{1 1}$ & $\mathbf{1 2}$ & $\mathbf{1 3}$ & $\mathbf{1 4}$ & $\mathbf{1 5}$ & $\mathbf{1 6}$ & $\mathbf{1 7}$ & $\mathbf{1 8}$ \\
\hline No. of text lines & 110 & 99 & 83 & 119 & 99 & 89 & 86 & 91 \\
\hline
\end{tabular}

Lesson structure. The lessons are divided in numbered themes (for themes $1,3,9$, and 13), as bulletted items and sub-themes (for themes 2, 5, 6, 7, $8,10,11,12,14,15,16,17$, and 18). The lessons are devoid of subthemes with topic 4.

Illustrative/Iconic material included per lesson. Topic 13 - The South American Continent encloses three photographs (one with llamas, one of an anaconda and one with Equatorian forests and swamps) and a map (the Map of minerals distribution in South America).

Amount of geographical terms. With Topic 14 - the USA - there are 116 terms - coasts, East, South, North, West, river, plain, plateaux, mountainous system, coast, shelf, tuna, salmon, shark, mackerel, industry, 
continent, resource, climate, wind, race, latitudinal, summer, longitude, warm climate, winter, borders, localisation, dessert, cyclone, countryside, hurricane, wood, islands, rainfall, temperature, prairie, steppe, natural park, ocean, seaside, countries, minerals, neighbours, coal, iron, copper, gold, agriculture, occupations, soils, agricultural products, citrus, tobacco, cotton, wheat, navigation, soy, corn, vegetables, sugar cane, hydroenergy, pineapple, pastures, fruit, orchards, animals, trade, energy, water resources, fishing, food and grocery industry, paper industry, chemical industry, harbour, automotive industry, petroleum products, finite products, electrical cars, scientific and medical gear, industrial regions, manufacture, film-making technology, fuel imports, cars, steel, tea, coffee, sugar, planes, computers, communication means, transport, telecommunications, railways, roads, Atlantic, revolution in communications, cities, air routes, space launch, spatial research, tourism, waterfall, environment, Native Americans, inhabitants, region, population, emigration, the English language, the Spanish language, services, urban citizens, life standards, the civilized, burger, and baseball (pp. 41-45).

Analysing these notions, we notice that these are key-concepts for the USA, comprising the features of this state. We emphasize that not all these notions have been introduced within this topic, but that they are only used to present the reality of the USA with the aid of geographical scientific language.

Amount of geographical denominations. As regards Topic 14 - The USA, there are 47 geographical names: Saint Lawrence, The Gulf of Mexico, the Appalachian Mountains, the Rocky Mountains, Colorado, Columbia, the Grand Canyon, Sierra Nevada, the Coast Mountains, California, the Central Tablelands, the USA, North America, Nevada, Arizona, the Death Valley, Alaska, the Hawaii Islands, the Aleutian Islands, the Pacific Ocean, Yellowstone Park, Mississippi, Missouri, Ohio, Tennessee, the Great Salt Lake, the Great Lakes, Georges Bank, the United Nations (UN), Manhattan, Texas, Michigan, New York, Erie, New England, the Statue of Liberty, Alabama, Hollywood, Sillicon Valley, Europe, Asia, Cape Kennedy, Launching Center NASA, the Niagara Falls, Los Angeles, Washington DC, World Bank (pp. 41-45). Unlike the previously learnt geography notions, the majority of the geographical denominations used in the text of this topic represent places in the USA. An exception are the names of European and Asia. We note that the quantity of the geographical denominations is optimum, considering the importance and extent of this state's area, but also the study level and students' age.

Drills related to maps. For Topic 3 - The Map, more exercises based on maps are included.

Example: the Map of the rural-population density in Kolhapur and the Map of the mean rainfall in Kolhapur are given. It is required that, relying on the analysis of both maps, students answer the following questions:

a. The map of the rural population density in Kolhapur

Which region features a density lower than 200 ?

Which region has the density ranging from 200 to 400 ? 
Which region features a density higher than 400 ?

In what part of the state there are the regions featuring the highest density?

b. The Map of the mean rainfall in Kolhapur

In what part of the district is the most profuse rainfall?

In what direction do the rains decrease?

Which is the minimum rainfall in the district?

Which is the maximum rainfall in the district? (p. 11)

(3) The Glossary includes 49 terms, but with more ample explanations. As example I have opted for is Topic 8 - Oceanic water movements. In this topic, the Glossary explains the following notions: waves, tide, oceanic currents, and plankton.

(4) Illustrative/iconic material. The coursebook consists of thirteen significant maps at the beginning of the coursebook (Map 1 - the Physical Map of Africa; Map 2 - the Physical Map of North America); at midcoursebook (Map 4 - the Map of Africa: natural vegetation; Map 5 - the Map of North America: natural vegetation; Map 6 - the Map of South America: natural vegetation; Map 7 - the Map of the Indian Ocean: the structure of the ocean bed; Map 8 - the Physical Map of the USA); at the end of the coursebook (Map 3 - the Physical Map of South America; Map 9 - the Physical Map of Brazil; Map 10 - the Physical Map of Egypt; Map 11 the Physical Map of Tanzania; Map 12 - the Physical Map of South Africa; Map 13 - the Map of South Africa: natural vegetation). Besides these 13 main maps, in the coursebook there are other 22 thematic maps.

THE $\mathbf{8}^{\text {TH }}$ GRADE COURSEBOOK (Board of Editors for Geography, 2013)

The Geography Standard Eight coursebook contains 76 pages. It opens with an excerpt from the Indian Constitution, Pledge, Contents, lessons, Glossary and maps and the 10 life skills. The data which I have presented for the life skills, Foreword and Pledge offer the same content as the one displayed in the $4^{\text {th }}$ grade coursebook. Albeit this coursebook does not belong to first secondary school, we present it so as to be able to compare it with the topics which are studied at Geography in Romania before students go to high school.

(1) Contents. Geography Standard Eight has topics of Practical Geography (1-3), Physical Geography (4-9), Environmental Geography (10), Human Geography (11-13), and of the Geography of states and continents (14-18). These are the topics belonging to the coursebook: 
1. Soaring into Space - skills 1, 5, 6 - pp. 1-2

2. Practical Geography - skills 1, 4, 5, 6 - pp. 3-5

3. Field Visits and Report Writing - skills 1, 3, 4, 5, 6, 9 - pp. 6-7

4. The Interior of the Earth - skills 4, 5, 6-pp. 8-9

5. Slow Earth Movements - skills 5, 6, 7 - pp. 10-11

6. Rapid Earth Movements - skills 5, 6, 7 - pp. 12-14

7. Rocks and Rock Types - skills 5, 6, 7 - pp. 15-16

8. Weather and Soils - skills 5, 6, 7-pp. 17-19

9. Agents of Erosion (1) - skills 5, 6, 7 - pp. 20-26

10. Agents of Erosion (2) - skills 5, 6, 7 - pp. 27-29

11. Man and the Natural Environment - skills 4, 5, 6, 7, 8 - pp. 30-32

12. Human Settlements - skills 5, 6, 8, 9 - pp. 33-34

13. Primary Occupations - skills 5, 6, 8, 9 - pp. 35-38

14. Secondary and Tertiary Occupations - skills 5, 6, 8, 9 - pp. 39-41

15. The Continent of Antarctica - skills 2, 3, 5, 6, 7, 8, 9 - pp. 42-44

16. The Continent of Australia - skills 2, 3, 5, 6, 7, 8, 9 - pp. 45-48

17. The Continent of Europe - skills 2, 3, 5, 6, 7, 8, 9 (lesson for self-study) - pp. 49-53

18. Germany - skills 2, 3, 5, 6, 7, 8, 9 - pp. 54-57

19. Italy - skills 2, 3, 5, 6, 7, 8, 9 - pp. 58-62

(2) Lesson analysis. In table 4, we show the span of the topics in the coursebook. The length varies between 32 rows and 154 rows. In this coursebook, there are tables for topics 4 ( 9 lines), 6 (5 lines), 7 ( 9 rows), 8 (6 rows), 12 (22 lines), and 13 (17 lines). There are explanations with topics 5 (6 lines), 9 ( 7 lines), 10 ( 7 lines), and 16 ( 7 lines).

Table 4a. Text span of the topics in Geography Standard Eight coursebook

\begin{tabular}{|l|l|l|l|l|l|l|l|l|l|l|}
\hline Topic & $\mathbf{1}$ & $\mathbf{2}$ & $\mathbf{3}$ & $\mathbf{4}$ & $\mathbf{5}$ & $\mathbf{6}$ & $\mathbf{7}$ & $\mathbf{8}$ & $\mathbf{9}$ & $\mathbf{1 0}$ \\
\hline No. of text lines & 54 & 53 & 61 & 44 & 37 & 55 & 41 & 83 & 154 & 89 \\
\hline
\end{tabular}

Table 4b. Text span of the topics in Geography Standard Eight coursebook

\begin{tabular}{|l|l|l|l|l|l|l|l|l|l|}
\hline Topic & $\mathbf{1 1}$ & $\mathbf{1 2}$ & $\mathbf{1 3}$ & $\mathbf{1 4}$ & $\mathbf{1 5}$ & $\mathbf{1 6}$ & $\mathbf{1 7}$ & $\mathbf{1 8}$ & $\mathbf{1 9}$ \\
\hline No. of text lines & 78 & 32 & 88 & 87 & 73 & 81 & 96 & 83 & 105 \\
\hline
\end{tabular}




\section{STUDY OF GEOGRAPHY COURSEBOOKS IN INDIA. AN EXAMPLE SET BY MAHARASHATRA STATE}

Lesson structure. The lessons are arranged in numbered themes (for topics $1,2,3,11,12,14,15,16,18$, and 19), as bulletted items and sub-themes (for topics 4, 5, 6, 7, 8, 9, 10, 13, and 17).

Illustrative/Iconic material included per lesson. Topic 14 - Secondary and Tertiary occupations - displays two maps: Map 1 - Iron Exploitation in Siderurgy (mines, refining plants, port in the Asansol region); Map 2 centres of Cotton and Fabrics Industry.

The amount of geographical terms. With Topic 17 - Europe, set as a self-study lesson - there are 83 terms (surface, localisation, research, scientific, region, physical and geographical features, North, South, slopes, peaks, continent, height, massif, people, islands, rivers, Industrial Revolution, resources, water, spring, seas, snow, shores, source, groceries, lake, circus, maps, canals, glacial lakes, wind, West, span, temperature, summer, winter, January, July, borders, East, West, latitude, oceanic currents, coasts, rainfall, longitude, temperature, rains, resources, forestal, oceans, interior seas, alpine, woods, coniferous, climatic areas, fauna, tundra, soil, island, plains, podzolic soils, chernozem, steppe, solonetz, salt, minerals, petrol, iron, magnesium, natural gases, environment, industrialisation, urbanisation, pollution, acid rains, discharges/floods, waste, deforestation, agriculture, territory, erosion, and decay). Unlike the USA topic, by scrutinising the notions employed in the presentation of Europe, we deem that the authors of this coursebook have, to a lesser extent, tackled the typical identity/aspects of this continent ( pp. 49-53).

Amount of geographical denominations. With a view to Topic 17 Europe - there are 32 geographical names: The Alps, Europe, The Black Forest, Africa, the Danube, mountain range, the Volga, the Pad, the Oder, the Rhine, the Rhon, the Prut, Pisa, the Botnic Gulf, the Scandinavian Peninsula, the Iberian Peninsula, the Eiffel Tower, the Jura, the Apenins, the Barents Sea, the North Sea, the Russian Plateau, the Caspic Sea, Kjolen, the Ural Mountains, the Caucasus, the Carpathians, Manchester, Frankfurt, the Apenins (pp. 49-53). Considering the analysis of the geographical denominations, used in the presentation of Europe, there results a brief approach, focused rather on the natural component and insignificantly on the human one, which is slightly dealt with ( 4 denominations).

Drills related to the schematic drawings. For Topic 2 - Practical Geography - there are several exercises.

Example: There are two drawings symbolising: 1. Slight slopes and steep slopes (in horizontal profile and plan, with the aid of degree curves); 2. Concave slopes and convex slopes (in horizontal profile and plan, with the aid of degree curves). Considering both drawings, try to understand the link between the slant angle of the slopes and the distances between the degree curves ( $p$ p. 3-5).

(3) The Glossary conveys 89 terms, featuring a high level of abstraction and scientific difficulty. For instance, with Topic 5 - The Slow Movements of the Earth - they explained in the Glossary the following 
words: energy, waves, slow movements of the Earth, fold mountains, mountain massifs (horst), and rift.

(4) Illustrative/iconic material. The coursebook encompasses six main maps, out of which one appears at the beginning of the coursebook (Map 1 - the Physical Map of Australia), four are placed in the middle (Map 2 - the Map of Australia: vegetation and animals; Map 3 - the Map of Europe: flora and fauna; Map 4 - the Physical Map of Europe; Map 5 - the Physical Map of Germany), and one at the end of the coursebook (Map 6 - the Physical Map of Italy) (the inside of the coursebook back cover). Besides these 6 main maps, in the coursebook there are 18 more thematic maps.

\section{DISCUSSION AND CONCLUSIONS}

The coursebooks in India make Geography learning attractive for students, and easy to teach. The scientific data is carefully selected from books, maps, catalogues, and from the Internet. The studied subject matter, the documents and the drills are adapted for students' study level. Generally, the coursebooks preserve the same structure, colours, graphic, and conventional signs.

The maps whose study is relevant for students are included in the coursebooks. These comprise too an array of thematic maps adjusted to the content of the topics and to students' study level, and are scientifically accurate, which are very important features of text books (Dulamă and Ilovan, 2006, 2008). The maps appear grouped at the beginning, in the middle and at the end of the coursebook, thus enabling an easy usage. The conventional signs employed in $5^{\text {th }}$ grade are just a few, their number and complexity increasing in the $6^{\text {th }}$ grade, whereas in the $7^{\text {th }}$ and $8^{\text {th }}$ grades, the maps encompass many more details.

By studying the contents of these coursebooks, students' amount of geography knowledge increases from year to year. The lessons are grouped to enable the context of developing students' geographical reasoning. In the $5^{\text {th }}$ grade, they provided basic information on the atmosphere and climate; in the $6^{\text {th }}$ grade, there is a shift from gist to detail, from generic to particular, learning about temperature and atmosphere pressure, wind and rainfall as elements of clime and atmosphere. In the $7^{\text {th }}$ grade, when continents and states are studied, these notions are reiterated and deepened by alluding to examples and some case studies. In the $8^{\text {th }}$ grade, they introduce the study of more difficult notions about oceans, the lithosphere and the like, which require imagination and creativity in order to understand them.

The way in which the text is devised and the exercises are included in the coursebook enables the use of problematisation as a didactic approach, by means of which students are determined to establish correlations and to search for answers. There are analysed the significant aspects of phenomena, necessary to explain the cause-effect connection (for instance, the relationship between woods, fauna, soil, and mineral resources). 


\section{STUDY OF GEOGRAPHY COURSEBOOKS IN INDIA. AN EXAMPLE SET BY MAHARASHATRA STATE}

When additional information is presented, it is stated that it is not meant to be part of assessments. Self-study is enhanced by carefully designed sets of questions and tasks and it is intended to have the students apply the knowledge acquired, to stimulate their imagination and creativity. Emphasis is on developing students' aquisition of notions and on their capacity to realise correlations between these so as they can make use of these on their own and out of school, developing students' competences - a significant part of geographical education (Dulamă and Ilovan, 2010, 2013).

The subject matter proper to a school year is not too dense (and this is still an unsolved aim of the geography national curriculum in Romania for a very long period - Dulamă and Ilovan, 2015). In the $5^{\text {th }}$ grade there are 21 topics, in the following school year there are 19 , in the $7^{\text {th }}$ grade -18 , out of which two are assigned to self-study, and in the $8^{\text {th }}$ grade -19 (here only one being set for self-study). Accounting for a mean 40-week span of the school year and considering a frequency of two Geography hours per week, there results a ratio of one topic addressed in four geography hours.

\section{References}

Board of Editors for Geography (2012). Geography Standard Seven. Maharashtra State Bureau of Textbook Production and Curriculum Research, Pune.

Board of Editors for Geography (2012). Geography Standard Six. Maharashtra State Bureau of Textbook Production and Curriculum Research, Pune.

Board of Editors for Geography (2013). Geography Standard Eight. Maharashtra State Bureau of Textbook Production and Curriculum Research, Pune.

Board of Editors for Geography (2013). Geography Standard Five. Maharashtra State Bureau of Textbook Production and Curriculum Research, Pune.

Board of Editors for Geography (2013). Geography Standard Four. Maharashtra State Bureau of Textbook Production and Curriculum Research, Pune.

Dulamă, M.E., \& Ilovan, O.-R. (2006). Developing Critical Thinking Using Specific Regional Geography Maps. Studia Universitas Babeş-Bolyai, Geographia, $L I(1), 137-146$.

Dulamă, M.E., \& Ilovan, O.-R. (2008). Geography and constructivism. Learning situations starting from images. Studia Universitas Babeş-Bolyai, Psychologia-Paedagogia, LII(2), 119-132.

Dulamă, M.E., \& Ilovan, O.-R. (2010). Competenţele formate la elevi prin studierea Geografiei Europei. In M.E. Dulamă, F. Bucilă, \& O.-R. Ilovan (Eds.), Tendinţe actuale în predarea şi învăţarea geografiei/Contemporary Trends in Teaching and Learning Geography (pp. 208-219). Cluj-Napoca: Editura Presa Universitară Clujeană.

Dulamă, M.E., \& Ilovan, O.-R. (2013). Contextul oficial al formării competenţelor la disciplina Geografie regională generală. In M.E. Dulamă, O.-R. Ilovan, H.V. Conţiu, \& G. Osaci-Costache (Eds.), Tendinte actuale în predarea si 


\section{MARI ANA-DOINA CîINEANU}

invatarea geografiei/Contemporary Trends in Teaching and Learning Geography. Cluj-Napoca: Editura Presa Universitară Clujeană.

Dulamă, M.E., \& Ilovan, O.-R. (2015). Development of the Geography School Curriculum in Romania, from the $18^{\text {th }}$ Century to 1989. Transylvanian Review, XXIV(1), 255-284. 